\title{
Phytochemical investigation of seeds of Trachyspermum ammi Linn. by GC-MS
}

\section{EKTA SHARMA ${ }^{1,2}$ AND B S ARORA ${ }^{3 *}$}

${ }^{1}$ Department of Chemistry, Banasthali Vidyapith University, Tonk, Rajasthan, India-304022

${ }^{2}$ Indian Institute of integrative medicine (CSIR), Canal road, Jammu Tawi, India-180001

${ }^{3}$ Department of Applied Sciences, D.A.V. Institute of Engg. \& Technology, Jalandhar, Punjab, India-144008

\section{*Email: bhupichem27@gmail.com}

Received: Received: January 28, 2017 | Revised: January 30, 2017 | Accepted: February 12, 2017

Published Online: March 01, 2017

The Author(s) 2017. This article is published with open access at www.chitkara.edu.in/publications

Abstract The present study embraces phytochemical investigation of the essential oil extracted from the mature seeds of Trachyspermum ammi Linn for different constituents by subjecting the oil to gas chromatography-mass spectrometry (GC-MS) analysis. The identification of the constituents is based upon retention indices and by comparison of their mass spectral fragmentation patterns against the commercial library mass spectra (Wiley, Nist etc.). Ellagic acid (EA), which is a natural phenol antioxidant, has been isolated from methanol extract from the mature seeds of Trachyspermum ammi Linn. Also, Thymol (Thl), a naturally occurring phenolic compound, has been crystallized by the reported standard procedure from oil extracted from these mature seeds. Both these compounds have been evaluated for their possible anti-cancer effect against a selected panel of human cancer cell lines by means of sulforhodamine B assay.

Keywords: Phytochemical study, Trachyspermum ammi, GC-MS, ellagic acid, Thymol, Anticancer effect, Cytotoxicity, Sulforhodamine B assay.

\section{INTRODUCTION}

Trachyspermum ammi Linn Synonym Carum copticum Linn (Family: Umbelliferae or Apiaceae) is widely recognized as ajowan or ajwain in India. Cultivation of this plant species was instigated in Egypt. It nurtures widely
Journal of Chemistry, Environmental Sciences and its Applications Vol. 3, No. 2 March 2017 pp. 91-100 
Sharma, E Arora, BS

around Mediterranean sea and in South-West Asia encompassing Iraq to India, particularly in North Indian parts including Punjab, Haryana, Uttar Pradesh, Maharashtra, Bihar, Madhya Pradesh, Rajasthan, Gujarat, and West Bengal and is a well-regarded medicinal herb from the earlier times. Trachyspermum ammi Linn (Omum) is a herbaceous winter annual that reaches up to height of $90 \mathrm{~cm}$, stem is profusely branched, nearly $7-9 \mathrm{~mm}$ thick near bottom and is striated all over. The leaves are pinnately divided, $24 \times 14 \mathrm{~cm}$ with clasping leaf bases bearing tiny white-petaled flowers in umbels that ultimately develop into small, oval-shaped, compressed, about $2 \mathrm{~mm}$ long grayish brown seeds marked with vertical stripes on their outer surface Joy et al. (2001); Asif et al. (2014).

Ajwain has been extensively employed in the traditional ayurvedic and unani medicines for different ailments and as enhancer of body's resistance Asif et al. (2014). Ajwain seeds, with their distinguishing aroma and sharp taste are extensively used as spice in cooking foods, for preservation and for getting oil for ultimate use in perfumery Ranjan et al. (2011). In traditional Indian medicinal system, paste of crushed seeds has been applied externally as a poultice for relieving colic pains, decoction made from the seeds has been used as remedy for diarrhea, amoebiasis, febrile conditions and stomach disorders including flatulence and indigestion as their active ingredients help to boost the digestive function of the intestinal tract by assisting release of the gut juices Rao et al. (2003). Hot dry fomentation of the ajwain fruits applied on chest has been commonly used as a asthma therapy Singh et al. (2003). T. ammi has been reported by Siripornvisal (2010) to possess antifungal, anti-inflammatory Thangam and Dhananjayan (2003), antiplatelet-aggregatory Srivastava (1988), antihypertensive, hepatoprotective, antispasmodic, broncho-dilating Gilani et al. (2005), antihyperlipidaemic Javed et al. (2006), digestive stimulant Vasudevan et al. (2000), kidney stone inhibitory Kaur et al. (2009), hypolipidemic Kumari and Prameela (1992), antitussive Boskabady et al. (2005), insecticidal Pandey et al. (2009), antifilarial Mathew et al. (2008), ameliorative Anilakumar et al. (2009), gestroprotective Ramaswamy et al. (2010), Histamine (H1) receptors inhibitory Boskabady and Shaikhi (2000), bronchodilatory Boskabady et al. (2007), diuretic \& anti-lithiasis Sabar (2010), male antifertility Kumar et al. (2011), antioxidant and antiviral effects Hussein et al. (2000). Being motivated by the extensive pharmacological activities and medicinal applications of Trachyspermum ammi Linn, we have analyzed the essential oil extracted from mature seeds for different constituents by subjecting the oil to hyphenated GC-MS technique. Ellagic acid has been isolated from methanol extract of mature seeds of this plant species. Thymol has been crystallized by the reported standard procedure of storing the oil 
extracted from mature seeds under low temperature condition for overnight Guenther (1950). These isolated compounds have been evaluated for their possible anticancer potential against a panel of selected human cancer cell lines by Sulforhodamine B assay Monks et al. (1991).

\section{MATERIALS AND METHODS}

\subsection{Experimental}

Thin Layer Chromatography (TLC) was executed on $2 \times 5 \mathrm{~cm}$ pre-coated silica gel 60 F254 aluminum plates (E. Merck). The developed chromatograms were envisaged under UV light (254-366 nm) and using $\mathrm{I}_{2}$. Silica gel 60-120 mesh was utilized for column chromatography. Melting points were measured with Buchi capillary apparatus. ${ }^{1} \mathrm{H}$ NMR was recorded on Bruker DPX 200 spectrometer operating at 200.13 MHz. IR spectra were recorded on Bruker Vector 22 and Perkin Elmer 1620 FT IR spectrophotometer, with absorption given in $\mathrm{cm}^{-1}$. Analytical HPLC analysis was conducted using Agilent 1100 series HPLC system consisting of quaternary pump and Sedex 75 ELSD detector connected in series with PDA detector to boost up its detection capability, $\mathrm{C}_{8}$ column reversed-phase (E-Merck, 4.0mm $\times 250 \mathrm{~mm}, 5 \mu \mathrm{m}$ particle size) maintained at $30^{\circ} \mathrm{C}$, quaternary pump, photodiode array detector, water-acetonitrile $(15: 85, \mathrm{v} / \mathrm{v})$ isocratic mobile phase at a flow rate of $0.6 \mathrm{ml}$ $\min ^{-1}$ using automatic sample injection module. LC-MS was performed using esquire 3000 (Bruker Daltonics) ion trap mass spectrometer with electrospray interface coupled with Agilent 1100 series LC using the same LC conditions as mentioned before.

Mass spectra were recorded on Varian GC-MS/MS 4000 instrument with workstation using electron impact method, FID detector, injector temperature $230^{\circ} \mathrm{C}$, column oven at $100^{\circ} \mathrm{C}$, held for 5 minutes to $250^{\circ} \mathrm{C}$ at the rate of 10 $\mathrm{deg} / \mathrm{min}$, held for 10 minutes, helium carrier gas with flow rate of $1 \mathrm{ml} / \mathrm{min}$ and Varian CP-SIL $8 \mathrm{CB}$ MS column $(30 \mathrm{~m} \times 0.32 \mathrm{~mm}, 1 \mu \mathrm{m}$ film thickness $)$, temperature $250^{\circ} \mathrm{C}$.

\subsection{Extraction of oil from seeds of Trachyspermum ammi Linn}

The air dried seeds of T. ammi Linn (500gm) were crushed, powdered and hydro-distilled in Clevenger-like apparatus for 12 hours to yield $20 \mathrm{ml}$ of essential oil, which was brownish in color and dried over anhydrous sodium sulphate. The essential oil was subjected to gas chromatography-mass spectrometry analysis. When this essential oil was stored at $0^{\circ} \mathrm{C}$ for overnight, colorless needles of thymol got separated.
Phytochemical investigation of seeds of Trachyspermum ammi Linn. by GC-MS 
Sharma, E

Arora, BS

\subsection{Isolation of EA}

The air dried material from previous step, after extraction of essential oil, was exhaustively extracted with petroleum ether at $60-80^{\circ} \mathrm{C}$ and then successively extracted with chloroform and then methanol by using Soxhlet apparatus. Both extracts were evaporated under vacuum to dryness. The methanol extract in the form of slurry was chromatographed on a silica gel column eluting with chloroform-methanol gradient. Fractions were collected $(100 \mathrm{ml}$ each) and monitored by TLC. Fractions of similar composition as determined by TLC analysis were combined and again chromatographed on silica gel column using n-hexane-ethyl acetate gradient as eluent in the order of increasing proportion of ethyl acetate, that yielded pure ellagic acid (EA).

\subsection{In vitro cytotoxicity of the isolated compounds}

In vitro cytotoxicity of the isolated compounds was assessed against the selected human cancer cell lines according to the standard procedure via protein-binding sulforhodamine B dye to estimate cell growth Skehan et al. (1990). The human cancer cell lines used in present study were acquired from National Cancer Institute, Frederick, U.S.A.

\section{RESULTS AND DISCUSSION}

\subsection{GC-MS analysis of the oil extracted from mature seeds of Trachyspermum ammi Linn}

Different constituents were identified from the essential oil from mature seeds of Trachyspermum ammi Linn on the basis of evaluation of their retention indices, EI-MS, MS/MS spectra and GC data with mass spectral databases of reference mass spectral libraries (Wiley and NIST) (Figure 1). The different chemical constituents identified along with their retention time $(\mathrm{Rt})$ and percentage composition in the essential oil from mature seeds are listed in table1.

\subsection{1 $\beta$ - Pinene}

The GC separated constituent of oil exhibited molecular ion peak at $136 \mathrm{~m} / \mathrm{z}$ in EI-MS/MS spectrum, analyzed as $\mathrm{C}_{10} \mathrm{H}_{16}$. The other fragments ion peaks were obtained at $\mathrm{m} / \mathrm{z} 121,107,93,77,69,63$ and 43 .

\subsection{2 $\alpha$ - Pinene}

The GC separated constituent of oil exhibited molecular ion peak at $136 \mathrm{~m} / \mathrm{z}$ in EI-MS/MS spectrum, analyzed as $\mathrm{C}_{10} \mathrm{H}_{16}$. The other fragments ion peaks were at $\mathrm{m} / \mathrm{z} 121,105,93,77,67$ and 63. 


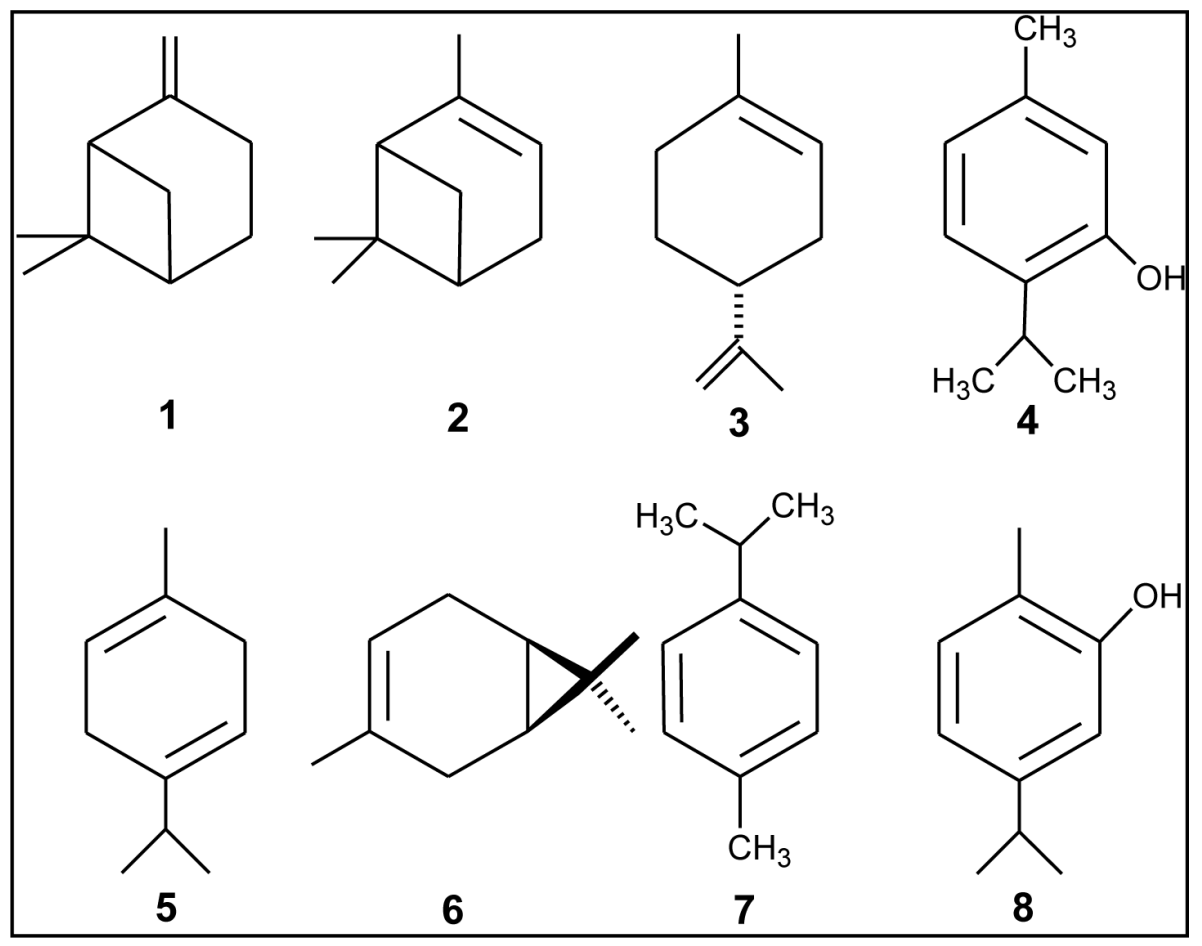

Phytochemical investigation of seeds of Trachyspermum ammi Linn. by GC-MS

Figure 1: Constituents identified from the essential oil from mature seeds of Trachyspermum ammi Linn.

Table 1: Composition (\%) of the major constituents of Trachyspermum ammi L. oil.

\begin{tabular}{ccccc}
\hline S. No. & Rt & Constituent & $\begin{array}{c}\text { Molecular } \\
\text { formula }\end{array}$ & $\begin{array}{c}\text { Percentage } \\
(\%)\end{array}$ \\
\hline 1. & 4.97 & $\beta$-Pinene & $\mathrm{C}_{10} \mathrm{H}_{16}$ & 2.5 \\
2. & 5.25 & $\alpha$-Pinene & $\mathrm{C}_{10} \mathrm{H}_{16}$ & 0.6 \\
3. & 6.47 & Limonene & $\mathrm{C}_{10} \mathrm{H}_{16}$ & 16.0 \\
4. & 7.62 & Thymol & $\mathrm{C}_{10} \mathrm{H}_{14} \mathrm{O}$ & 26.9 \\
5. & 16.32 & $\gamma$-Terpinene & $\mathrm{C}_{10} \mathrm{H}_{16}$ & 16.5 \\
6. & 16.42 & $\Delta$-Carene & $\mathrm{C}_{10} \mathrm{H}_{16}$ & 9.4 \\
7. & 16.60 & p-Cymene & $\mathrm{C}_{10} \mathrm{H}_{14}$ & 19.0 \\
8. & 16.70 & Carvacrol & $\mathrm{C}_{10} \mathrm{H}_{14} \mathrm{O}$ & 8.9 \\
\hline
\end{tabular}


Sharma, E

Arora, BS

\subsubsection{Limonene}

The GC separated constituent of oil exhibited molecular ion peak at $136 \mathrm{~m} / \mathrm{z}$ in EI-MS/MS spectrum, analyzed as $\mathrm{C}_{10} \mathrm{H}_{16}$. The other fragments ion peaks were at $\mathrm{m} / \mathrm{z} 119,107,93,77,66,63$ and 43.

\subsubsection{Thymol}

The GC separated constituent of oil exhibited molecular ion peak at $150 \mathrm{~m} / \mathrm{z}$ in EI-MS/MS spectrum, analyzed for $\mathrm{C}_{10} \mathrm{H}_{14} \mathrm{O}$. The other fragments ion peaks were at $\mathrm{m} / \mathrm{z} 135,115,107,91,77$ and 65 .

\subsection{5 $\gamma$-Terpinene}

The GC separated constituent of oil exhibited molecular ion peak at $136 \mathrm{~m} / \mathrm{z}$ in EI-MS/MS spectrum, analyzed as $\mathrm{C}_{10} \mathrm{H}_{16}$. The other fragments ion peaks were at $\mathrm{m} / \mathrm{z} 107$ and 121 .

\subsection{6 $\Delta$-3-Carene}

The GC separated constituent of oil exhibited molecular ion peak at $136 \mathrm{~m} / \mathrm{z}$ in EI-MS/MS spectrum, analyzed as $\mathrm{C}_{10} \mathrm{H}_{16}$. The other fragments ion peaks were at $\mathrm{m} / \mathrm{z} 121,105,107,93,77$ and 45 .

\subsection{7 p-Cymene}

The GC separated constituent of oil exhibited molecular ion peak at $134 \mathrm{~m} / \mathrm{z}$ in EI-MS/MS spectrum, analyzed as $\mathrm{C}_{10} \mathrm{H}_{14}$. The other fragments ion peaks were at $\mathrm{m} / \mathrm{z} 119,105,91,77$ and 65 .

\subsubsection{Carvacrol}

The GC separated constituent of oil exhibited molecular ion peak at $150 \mathrm{~m} / \mathrm{z}$ /MS spectrum, analyzed as $\mathrm{C}_{10} \mathrm{H}_{14} \mathrm{O}$. The other fragments ion peaks were at $\mathrm{m} / \mathrm{z} 135,115,107,91,77$ and 66 .

\subsubsection{Ellagic acid (EA)}

HPLC: Under the LC conditions employed as stated in experimental section, the purified ellagic acid got eluted at retention time $(\mathrm{Rt})$ of 3.3 minutes, giving a single peak.

LC-ESI-MS: The LC peak exhibited a molecular adduct at m/z 302.1 under positive ionization mode of ESI-MS, without any fragment ions produced.

IR $\left(\mathrm{CHCl}_{3}, \mathrm{~cm}^{-1}\right)$ : Ellagic acid showed a strong peak at $1617.21 \mathrm{~cm}^{-1}$ representing an aromatic system beside strong bands at $3413.73,3474.44 \mathrm{~cm}^{-1}$ due to hydroxyl groups and a sharp peak at $1692.59 \mathrm{~cm}^{-1}$ due to lactone carbonyl. 


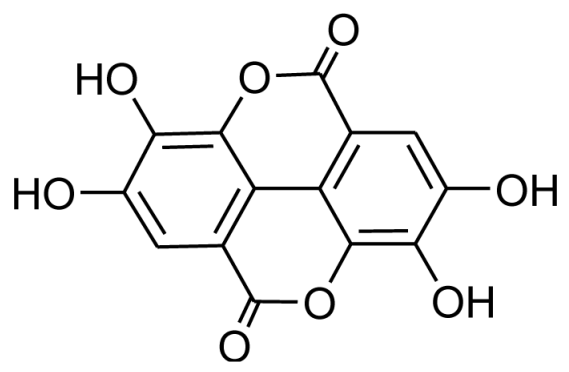

Phytochemical investigation of seeds of Trachyspermum ammi Linn. by GC-MS

${ }^{1}$ H NMR (200 MHz, CD OD): Ellagic acid showed one singlet for aromatic protons at $\delta 7.28$ along with a singlet at $\delta 4.61 \mathrm{ppm}$, which disappeared on $\mathrm{D}_{2} \mathrm{O}$ exchange.

Ellagic acid responded to phenolic test $\left(\mathrm{FeCl}_{3}\right)$ and upon acetylation with acetyl chloride using dry pyridine, formed acetate, that exhibited one singlet at $\delta 7.26 \mathrm{ppm}$ for aromatic protons and a singlet at $\delta 2.17 \mathrm{ppm}$ for acetyl protons in ${ }^{1} \mathrm{H}$ NMR (200 $\left.\mathrm{MHz}, \mathrm{CDCl}_{3}\right)$.

\subsection{In vitro cytotoxicity of the isolated compounds}

The results in terms of percent growth inhibition for the tested compounds along with the standards have been summarized in Table 2.

Table 2: Cytotoxic effect of the isolated compounds.

\begin{tabular}{|c|c|c|c|c|c|c|}
\hline \multicolumn{2}{|c|}{ Cell Line Type } & \multirow{3}{*}{$\begin{array}{l}\text { Lung } \\
\text { A-549 }\end{array}$} & \multirow{3}{*}{$\begin{array}{r}\text { Prostate } \\
\text { DU-145 } \\
\text { G }\end{array}$} & \multirow{2}{*}{$\begin{array}{c}\text { Leukemia } \\
\text { THP-1 }\end{array}$} & \multirow{2}{*}{$\begin{array}{c}\begin{array}{c}\text { Neuro } \\
\text { blastoma }\end{array} \\
\text { IMR-32 }\end{array}$} & \multirow{3}{*}{$\frac{\text { Breast }}{\text { MCF-7 }}$} \\
\hline & & & & & & \\
\hline Sample Code & Conc. & & & wth Inhibit & n $(\%)$ & \\
\hline \multirow[t]{2}{*}{ THY } & $1 \times 10-6 M$ & 50 & 0 & 9 & 21 & 55 \\
\hline & $1 \times 10-5 M$ & 55 & 20 & 15 & 28 & 68 \\
\hline \multirow[t]{2}{*}{ EA } & $1 \times 10-6 M$ & 56 & 33 & 65 & 52 & 42 \\
\hline & $1 \times 10-5 M$ & 72 & 50 & 81 & 66 & 54 \\
\hline Paclitaxel & $1 \times 10-5 M$ & 61 & - & - & - & - \\
\hline Mitomycin C & $1 \times 10-5 M$ & - & 58 & - & - & - \\
\hline 5-Fluorouracil & $2 \times 10-5 M$ & - & - & 72 & - & - \\
\hline Adriamycin & $1 \times 10-6 M$ & - & - & & 85 & 76 \\
\hline
\end{tabular}


Sharma, E

Arora, BS

From the resulting cytotoxicity data, ellagic acid (EA) has been found to possess considerable cytotoxicity with more than $70 \%$ growth inhibition at $1 \times 10^{-5} \mathrm{M}$ concentration for A-549 (Lung) and THP-1 (Leukemia) human cancer cell lines, which is comparable to the standard anticancer drugs used for this study. Not much significant effect of thymol (Thl) has been observed on the tested cancer cell lines.

\section{CONCLUSION}

The present work reveals analysis of the essential oil extracted from mature seeds of Trachyspermum ammi Linn for different constituents by gas chromatography-mass spectrometry (GC-MS) analysis. Also, ellagic acid (EA), a pharmacologically significant polyphenol, has been isolated from methanolic extract from the mature seeds and thymol (Thl) has been crystallized by storing the oil extracted from mature seeds of this plant species under low temperature condition. Both the isolated compounds have been evaluated for their anticancer potential against a panel of selected human cancer cell lines by sulforhodamine B assay. The activity results obtained have demonstrated that ellagic acid (EA) possesses considerable cytotoxic activity against some human cancer cell lines used for the present study.

\section{ACKNOWLEDGMENTS}

Authors are exceedingly thankful to Dr. R. K. Khajuria and Mr. Rajneesh Anand, Instrumentation division, IIIM (CSIR), Jammu, India for their support in instrumental analysis and Dr. A. K. Saxena, pharmacology division, IIIM (CSIR), Jammu, India for his support in analysis of cytotoxicity of the samples.

\section{REFERENCES}

[1] Anilakumar, K. R., Saritha, V., Khanum, F., \& Bawa, A. S. (2009). Ameliorative effect of ajwain extract on hexachlorocyclohexane-induced lipid peroxidation in rat liver. Food Chem Toxicol., 47, 279-282.

[2] Asif, H. M., Sultana, S., \& Akhtar, N. (2014). A panoramic view on phytochemical, nutritional, ethanobotanical uses and pharmacological values of Trachyspermum ammi Linn. Asian Pac J Trop Biomed., 4(2), S545-S553

[3] Ayurvedic Pharmacopoeia of India (1999-2011). Department of Ayush, Ministry of Health and Family Welfare, Government of India, 1, 170-171.

[4] Boskabady, M. H., \& Shaikhi, J. (2000). Inhibitory effect of Carum copticum on Histamine (H1) receptors of isolated guinea-pig tracheal chains. J Ethnopharmacol., 69(3), 217-227.

[5] Boskabady, M. H., Alizadeh, M., \& Jahanbin, B. (2007). Bronchodilatory effect of Carum copticum in airways of asthmatic patients. Therapie, 62(1), 23-29. 
[6] Boskabady, M. H., Jandaghi, P., Kiani, S., \& Hasanzadeh, L. (2005). Antitussive effect of Carum copticum in guinea pigs. J Ethnopharmacol., 97, 79-82.

[7] Gilani, A. H., Jabeen, Q., Ghayur, M. N., Janbaz, K. H., \& Akhtar, M. S. (2005). Studies on the antihypertensive, antispasmodic, bronchodilator and hepatoprotective activities of the Carum copticum seed extract. Journal of Ethnopharmacol., 98, 127-135.

[8] Guenther, E. (1950). The essential oils (pp. 551-552), volume IV. D. Van Nostrand Co. Inc., New York.

[9] Hussein, G., Miyashiro, H., Nakamura, N., Hattori, M., Kakiuchi, N., \& Shimotohno, K. (2000). Inhibitory effects of Sudanese medicinal plant extracts on Hepatitis C Virus (HCV) protease. Phytother Res., 14(7), 510-516.

[10] Javed, I., Iqbal, Z., Rahman, Z. U., Khan, F. H., Muhammad, F., Aslam, B., \& Ali, L. (2006). Comparative antihyperlipidaemic efficacy of Trachyspermum ammi extracts in Albino rabbits. Pak. Vet. J, 26, 23-29.

[11] Joy, P. P., Thomas, J., Mathew, S., Jose, G., \& Joseph, J. (2001). Aromatic plants. In T. K. Bose, J. Kabir, P. Das, \& P. P. Joy (Ed.), Tropical Horticulture (pp. 633733), Vol. 2, Calcutta: Naya Prokash.

[12] Kaur, T., Bijarnia, R., Singla, S., \& Tandon, C. (2009). Purification and characterization of an anticalcifying protein from the seeds of Trachyspermum ammi (L.). Protein Pept. Letter., 16(2), 173-181.

[13] Kumar, S., Reddy, R., Manasa, G., Vanaja, P., Sirisha, G., \& Astalakshmi, N. (2011). Antifertility effect of Trachyspermum ammi (Linn) Sprague fruits on male rats. International Journal of Pharmaceutical \& Biological Archives, 2(2), 705-709.

[14] Kumari, K. S., \& Prameela, M. (1992). Effect of incorporating Carum copticum seeds in a high fat diet for albino rats. Med Sci Res., 20, 219-220.

[15] Lim, T. K. (2013). Edible medicinal and non-medicinal plants (pp. 60-71), New York: Springer.

[16] Mathew, N., Bhattacharya, S. M., Perumal, V., Muthuswamy, K. (2008). Antifilarial Lead Molecules Isolated from Trachyspermum ammi. Molecules, 13, 2156-2168.

[17] Monks, A., Scudiero, D., Skehan, P., Shoemaker, R., Paull, K., Vistica, D., Hose, C., Langley, J., Cronise, P., Vaigro-Wolff, A., Gray-Goodrich, M., Campbell, H., Mayo, J., \& Boyd, M. (1991). Feasibility of a high-flux anticancer drug screen using a diverse panel of cultured human tumor cell lines. J Natl Cancer Inst, 83, 757-766.

[18] Pandey, S., Upadhyay, S. \& Tripathi, A. (2009). Insecticidal and repellent activities of thymol from the essential oil of Trachyspermum ammi (Linn) Sprague seeds against Anopheles stephensi. Parasitol. Res., 105, 507-512.

[19] Ramaswamy, S., Sengottuvelu, S., Sherief, S., Jaikumar, S., Saravanan, R., Prasadkumar, C., \& Sivakumar, T. (2010). Gastroprotective activity of ethanolic extract of Trachyspermum ammi fruit. Int J Pharm Biosci, 1(1), 1-15.

[20] Ranjan, B., Singh, M., Singh, S. R., \& Singh, R. B. (2011). Medicinal uses of Trachyspermum ammi: a review. Pharm Res., 5, 247-258.

[21] Rao, R. R., Patel, K., \& Srinivasan, K. (2003). In vitro influence of spices and spiceactive principles on digestive enzymes of rat pancreas and small intestine. Nahrung, 47(6), 408-412.
Phytochemical investigation of seeds of Trachyspermum ammi Linn. by GC-MS 
Sharma, E

Arora, BS
[22] Sabar, A. G. (2010). Lithotripsy of different urinary tract stones by using seeds of Carum copticum. Iraqi Journal of Pharmaceutical Sciences, 19(2), 38-41.

[23] Singh, V. K., Singh S., \& Singh, D. K. (2003). Pharmacological effects of spices. In Recent Progress in Medicinal Plants Phytochemistry Pharmacology (pp. 321-353). Vol. 2. Houston, Texas, USA: Stadium Press.

[24] Siripornvisal, S. (2010). Antifungal activity of Ajowan Oil against Fusarium oxysporum. KMITL Sci. Tech. J., 10(2), 45-51.

[25] Skehan, P., Storeng, R., Scudiero, D., Monks, A., McMohan, J., Vistica, D., Warren, J., Bokesch, H., Kenney, S., \& Boyd, M. (1990). New colorimetric cytotoxic Assay for Anticancer- Drug Screening. Journal of the National Cancer Institute, 82, 1107-1112.

[26] Srivastava, K. C. (1988). Extracts of a spice-omum (Trachyspermum ammi) shows anti-aggregatory effects and alters arachidonic acid metabolism in human platelets Prostaglandins Leukot Essent. Prostaglandins Leukot Essent Fatty Acids, 33, 1-6.

[27] Thangam, C., \& Dhananjayan, R. (2003). A ntiinflammatory potential of the seeds of Carum copticum linn. Indian Journal of pharmacology, 35, 388-391.

[28] Vasudevan, K., Vembar, S., Veeraraghavan, K., \& Haranath, P. S. (2000). Influence of intragastric perfusion of aqueous spice extracts on acid secretion in anesthetized albino rats. Indian J Gastroenterol., 19, 53-56. 